\title{
The impact of CYP21A2 (P30L/I172N) genotype on female fertility in one family
}

\author{
Mirjana Kocova ${ }^{1 *} \mathbb{D}$, Violeta Anastasovska ${ }^{1}$ and Iskra Bitovska²
}

\begin{abstract}
Background: The simple virilizing (SV) form of congenital adrenal hyperplasia (CAH) is an autosomal recessive disorder usually caused by steroid 21-hydroxylase deficiency due to I172N missense mutation at the CYP21A2 gene. Clinical presentation encompasses virilization of external genitalia in newborn females and pseudoprecocious puberty in both sexes, due to reactive androgen overproduction. The aim of this study was to present two sisters with an SV form of CAH and distinctive genotype, detected and treated since childhood with a poor compliance and poor metabolic control hindering the fertility.

Case presentation: We retrospectively reviewed the clinical, biochemical, and molecular data of two sisters with $\mathrm{CAH}$ a 46,XX karyotype when they reached an age of 35 and 38 years, respectively, and were attempting conception for several years. They had been diagnosed with SV form of CAH at the age of 7 and 9 years, respectively, by the standard clinical and biochemical procedures, presenting with severe virilization due to androgen excess. Follow-up was performed through standard methods of measurement of 17-OHP, testosterone, and ACTH. Clitoroplasty with vaginoplasty was performed at the age of 18 in the older sister. Using PCR/ACRS, we performed molecular analysis of the nine most common point CYP21A2 mutations in the patients and family members. The P30L/II72N genotype was observed in both sisters. They had inadequate metabolic control due to noncompliance until decision to conceive. IVF was performed three times in the older sister without success. Sufficient follicles were harvested and fertilized; however, the embryos were lost 3-5 days after implantations. The younger sister is preparing for IVF. She underwent follicle harvesting and the embryos were frozen awaiting appropriate hormonal balance for embryo transfer. The 1172N mutation in the heterozygote state was observed in their other two sisters, whose fertility was unaffected.
\end{abstract}

Conclusions: Despite significant improvements over the last years in achieving fertility in female patients with SV $\mathrm{CAH}$, it is highly dependent upon the severity of virilization and the metabolic control. The role of P30L mutation in infertility and unsuccessfully assisted reproduction remains to be elucidated.

Keywords: Congenital adrenal hyperplasia, CYP21A2 gene, Infertility, Simple virilizing form

\section{Background}

Congenital adrenal hyperplasia (CAH) encompasses a group of genetic disorders of adrenal steroidogenesis, characterized by impaired adrenal cortisol and aldosterone production with increased androgen secretion $[1,2]$. Approximately $90-95 \%$ of $\mathrm{CAH}$ cases are caused by steroid 21-hydroxylase deficiency (21OHD, MIM

\footnotetext{
*Correspondence: mirjanakocova@yahoo.com

1 Department of Endocrinology and Genetics, University Clinic of Pediatrics, Medical Faculty, Ss. Cyril and Methodius University, Vodnjanska 17, 1000 Skopje, Republic of Macedonia

Full list of author information is available at the end of the article
}

201910), resulting from mutations in the CYP21A2 gene and leading to a broad spectrum of clinical presentations, ranging from the severe classical salt-wasting (SW) and simple virilizing (SV) forms to the mild non-classical form of $\mathrm{CAH}[3,4]$. The severe classical form occurs in 1 in 10,000-15,000 Caucasians [1]. Approximately $67 \%$ of classical $\mathrm{CAH}$ patients are classified as salt wasting, while $33 \%$ are classified as simple virilizing form with cortisol deficiency and virilization [5]. Sexual ambiguity at birth in females without severe or life-threatening sodiumdeficiency symptoms in newborns points to SV form of $\mathrm{CAH}$. Ambiguous female genitalia occur only when excessive androgens are present during fetal life, and the

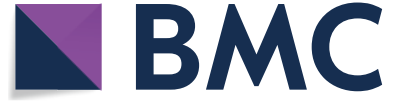

(c) The Author(s) 2019. This article is distributed under the terms of the Creative Commons Attribution 4.0 International License (http://creativecommons.org/licenses/by/4.0/), which permits unrestricted use, distribution, and reproduction in any medium, provided you give appropriate credit to the original author(s) and the source, provide a link to the Creative Commons license, and indicate if changes were made. The Creative Commons Public Domain Dedication waiver (http://creativecommons.org/ publicdomain/zero/1.0/) applies to the data made available in this article, unless otherwise stated. 
degree of masculinization is dependent on the timing of such exposure. If the fetus is exposed to excessive androgens after the 12th gestational week, when the vagina and urethra have separated, only clitoral hypertrophy occurs. However, the full range of genital anomalies includes complete fusion of the labioscrotal folds and a phallic urethra, partial fusion of the labioscrotal folds, precocious pubarche, clitoromegaly with a shallow vagina, as well as accelerated growth and skeletal maturation [5, 6]. Hirsutism, oligomenorrhea, and infertility are consequences later we face in life $[7,8]$.

Defects of the CYP21A2 gene are divided into three groups according to residual enzyme activity, depending on the nature of the mutations $[9,10]$. The first group consists of mutations abolishing enzyme activity and is thus associated with the SW form. The second group, found in patients with the SV form, consists mainly of the missense I172N mutation [11] with very low residual 21-hydroxylase activity, however sufficient to prevent neonatal SW $[12,13]$. The third group includes mutations such as P30L [14] and V281L [12] that produce enzymes retaining $20-70 \%$ of the normal activity and are associated with the non-classical form. There is a good relationship between the genotype and clinical presentation in $\mathrm{CAH}$, including SV form; however, different combinations of CYP21A2 mutations have different effects on fertility $[15,16]$. Spontaneous puberty does occur in affected girls; however, cycles are frequently irregular [17]. Anovulatory cycles and ovarian cysts are not rare [18]. Older reports from the literature indicate a very low conception rate in women with $\mathrm{CAH}$, especially in the SW form ranging from 0 to $10 \%[8,15]$. Fertility rate has significantly improved over time reaching up to $90 \%$ in the classical forms. Spontaneous or assisted pregnancies have been reported in women attempting conception [19]. Both successful and unsuccessful in vitro fertilization (IVF) have been described [20]. Appropriate treatment, regular follow-up and patient compliance are crucial factors for successful pregnancy. However, psychosocial factors or sexual orientation and will to become pregnant influence the fertility rate.

\section{Case presentation}

We present two sisters at the age of 35 and 38 years with female external genitalia a 46,XX karyotype and clitoromegaly since birth, followed up for 24 and 31 years, respectively. The patients were born in a family of Albanian ethnicity, with six children, all females. No consanguinity between the parents was reported. Two children died shortly after birth with an unknown cause of death. The mother conceived spontaneously, she had never been treated with any drugs or hormones during pregnancy and she had no signs of androgen excess. There was no family history of infertility or ambiguous genitalia. Classical CAH had been suspected in both sisters at the first clinical examination by a pediatric endocrinologist at the age of 7 and 9 years, respectively. Perineal examination revealed enlarged clitoris of $1.5 \mathrm{~cm}$ with narrow introitus vaginae in the older sister (Tanner stage 2) and of $1 \mathrm{~cm}$ with normal introitus vaginae in the younger sister (Tanner stage 1). Labia majora, minora, and urethral orifice were normal. Ultrasound showed normal uterus with hypoplastic vagina and normal internal genitals in the younger sister. High serum levels of 17-OHP and testosterone, elevated urinary corticosteroids and ketosteroids, as well as low plasma cortisol, confirmed $\mathrm{CAH}$ (Table 1), according to the standard criteria [21]. Nine common pseudogene-derived CYP21A2 point mutations: P30L, IVS2, 8 bp deletion in exon 3 (G110 $\Delta 8$ nt), I172N, exon 6 cluster (I236N, V237E, M239K), F306+ T, V281L, Q318X, and R356W were analyzed in the patients and family members, using the PCR/ACRS method, followed by restriction enzyme digestion, as previously described [22]. PCR products were directly run on $2 \%$ agarose gel electrophoresis, separately for each mutation (Fig. 1). The mutation analysis allowed not only mutation detection, but also determination of the zygosity of the individual mutations. Both patients were compound heterozygotes with different mutations on each chromosome (one severe, I172N, and one mild, P30L). The I172N mutation in the heterozygote state was observed in their other two adult sisters, who had no clinical manifestation of $\mathrm{CAH}$ and had normal child deliveries. The patients had inherited the missense P30L mutation from the carrier father. DNA from the deceased mother of this family was not available for analysis, but we could deduce that the mother was a heterozygous carrier of I172N mutation because of the distribution of this mutation in all of her living children.

Treatment with hydrocortisone $\left(15-20 \mathrm{mg} / \mathrm{m}^{2}\right)$ was introduced; however, compliance and metabolic control were poor (during the follow-up the levels of 17-OHP and urinary ketosteroids and corticosteroids were continuously elevated, Table 1 ). The secondary sex characteristics were extremely delayed, breasts failed to develop, and despite significant hirsutism, subtle pubarche appeared at the age of 16 years accompanied by significant virilization with male distribution of body hair, a strong beard requesting daily shaving, male bodily features, breast hypoplasia, a prominent Adams' apple, and a deep voice (Fig. 2). Reconstructive clitoroplasty with vaginoplasty was performed in the older sister at the age of 18 years, whereas the younger sister underwent no surgical procedures. Menarche was delayed to 16 and 18 years, respectively and there were menstrual irregularities with scanty flow. Noncompliance and deviation from 
Table 1 Baseline evaluation and management in infancy and childhood

\begin{tabular}{|c|c|c|}
\hline & Patient 1 & Patient 2 \\
\hline Gender assignment at birth & Female & Female \\
\hline Age at diagnosed of $\mathrm{CAH}$ & 7 years & 9 years \\
\hline Degree of genital virilization at birth & Prader stage 1 clitoromegaly (1 cm) & Prader stage 2 clitoromegaly $(1.5 \mathrm{~cm})$ \\
\hline Age at start of menarche & 16 years irregularly & 18 years irregularly \\
\hline $\mathrm{CAH}$ genetics & Compound heterozygote & Compound heterozygote \\
\hline CYP21A2 mutations & P30L/I172N & $\mathrm{P30L/I172N}$ \\
\hline $\mathrm{CAH}$ classification at diagnosis & Simple virilizing & Simple virilizing \\
\hline \multicolumn{3}{|c|}{ Steroid hormone results at the time of diagnosis of $\mathrm{CAH}$-before treatment } \\
\hline 17-OHP (ref. 0.3-3) & $>75 \mathrm{nmol} / \mathrm{L}$ & $>75 \mathrm{nmol} / \mathrm{L}$ \\
\hline Testosterone (ref. 0.3-3) & $29.8 \mathrm{nmol} / \mathrm{L}$ & $19.6 \mathrm{nmol} / \mathrm{L}$ \\
\hline Urinary 17-ketosteroids (ref. 13.8-43.4) & $88.7 \mathrm{dU} / \mu \mathrm{mol}$ & $50.6 \mathrm{dU} / \mu \mathrm{mol}$ \\
\hline Urinary 17-corticosteroids (ref. 11.7-36.6) & $46.8 \mathrm{dU} / \mu \mathrm{mol}$ & $36.6 \mathrm{dU} / \mu \mathrm{mol}$ \\
\hline \multicolumn{3}{|c|}{ Steroid hormone results — with hydrocortisone $20 \mathrm{mg} / \mathrm{m}^{2}$ treatment } \\
\hline 17-OHP & $56.5 \mathrm{nmol} / \mathrm{L}$ & $29.5 \mathrm{nmol} / \mathrm{L}$ \\
\hline Testosterone (ref.<0.1-0.96) & $2.8 \mathrm{ng} / \mathrm{mL}$ & $3.2 \mathrm{ng} / \mathrm{mL}$ \\
\hline Urinary 17-ketosteroids & $20 \mathrm{dU} / \mu \mathrm{mol}$ & $32.3 \mathrm{dU} / \mu \mathrm{mol}$ \\
\hline Urinary 17-corticosteroids & $18.8 \mathrm{dU} / \mu \mathrm{mol}$ & $16.6 \mathrm{dU} / \mu \mathrm{mol}$ \\
\hline
\end{tabular}

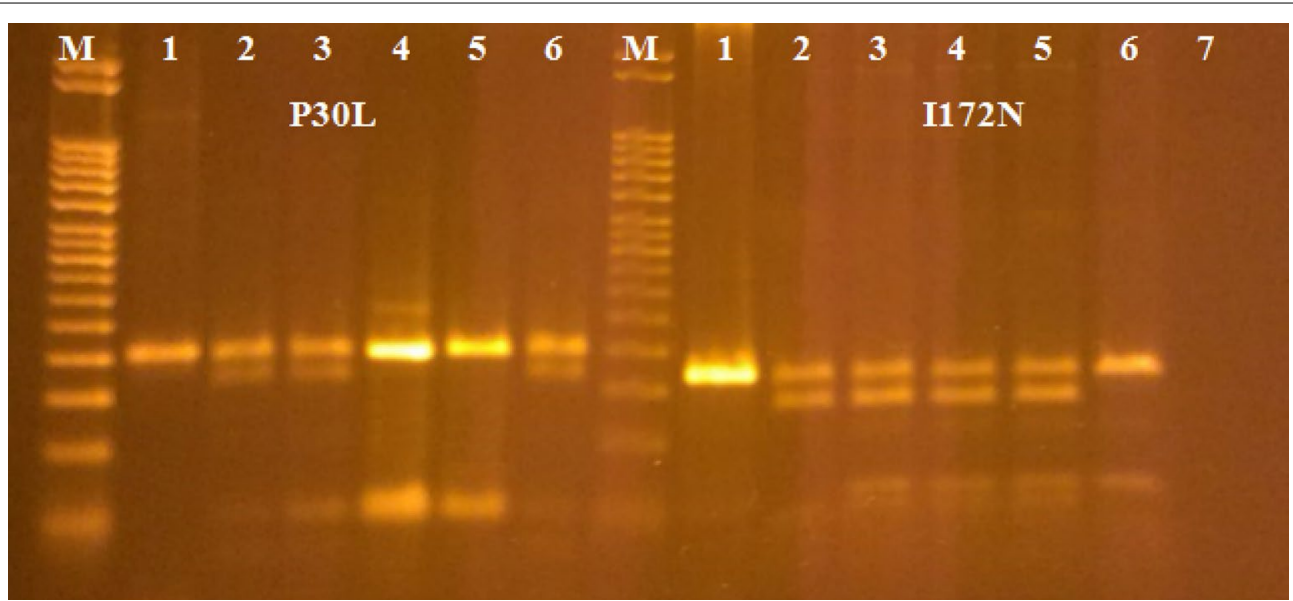

Fig. 1 ACRS/PCR mutational analysis of the CYP21A2 gene; line 1—PCR II product; lines 2, 3-compound heterozygous patients with genotype P30L/I172N; lines 4, 5—others two sisters, heterozygotes for I172N; line 6-father, heterozygote for P30L; line 7—blank; M—marker (50 bp)

the hydrocortisone dosage were noticed in both sisters in different periods of adult life and there was a period of 6-8 years when they were lost to follow-up. After the decision to conceive the therapy was regularly taken, but with a modest result. At 30 and 33 years, respectively, they had started visiting a gynecologist due to oligomenorrhea, hirsutism, and infertility. Hormonal findings at this stage are presented in Table 2. Ovarian ultrasound confirmed polycystic ovaries in both sisters. After hormonal preparation IVF was performed in the older sister three times, thus far with no success. Sufficient folicles were harvested and fertilized; however, the embryos were lost 3-5 days after implantations. The younger sister is preparing for IVF. She underwent follicle harvesting and the embryos were frozen awaiting appropriate hormonal balance for embryo transfer.

\section{Discussion and conclusions}

Excessive androgen production, during the genital differentiation period, will cause masculinization of the external genitalia in a fetus of female gonadal sex ranging from mild clitoral enlargement through varying degrees of fusion of the labioscrotal folds, to the profound 


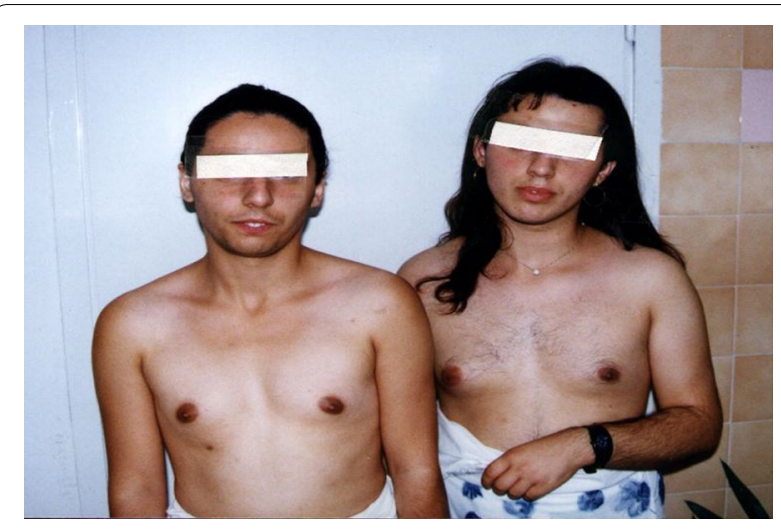

Fig. 2 Male distribution of body hair in sisters with simple virilizing $\mathrm{CAH}$

morphologic anomaly of a penile urethra, which is very rare $[5,6]$.

We observed an interesting pattern of the CYP21A2 mutational spectrum in two sisters, presenting with clitoromegaly since birth. They were compound heterozygotes for the I172N and P30L mutations with clinical manifestation of classical SV form of CAH. The I172N mutation results in production of an enzyme with 1-2\% of normal activity and is mainly associated with SV CAH [11], because this activity is sufficient to prevent SW $[12,13]$. Virilization of the external genitalia in newborn females and pseudoprecocious puberty in both sexes is due to reactive androgen overproduction. The second mutation was a mild P30L mutation resulting in more than $30 \%$ of enzyme activity. Although, the P30L allele is still categorized as a non-classical mutation, patients carrying it tend to have pronounced androgen excess [14, 23]. Our findings support the role of the P30L mutation in severe virilization (clitoromegaly, body hair, male body features, breast hypoplasia, prominent Adams' apple, and deep voice). In the previous study, we found high prevalence of P30L among Macedonian (30\%) and Serbian (40\%) patients with SV form of CAH [24].

In females with $\mathrm{CAH}$, the degree of fertility depends on the phenotype. It is significantly reduced in SW patients, mildly reduced in SV patients, and normal in patients with the non-classical form. Fertility rates of $60-80 \%$ have been reported in women with SV CAH [8]. Several factors have been suggested to contribute to the impaired fertility in $\mathrm{CAH}$ females: adrenal overproduction of androgens and progestins (17-OHP and progesterone), ovarian hyperandrogenism, polycystic ovary syndrome, ovarian adrenal rest tumors, neuroendocrine factors, genital surgery, and psychological factors such as delayed psychosexual development, reduced sexual activity and low maternal feelings [25, 26]. Adrenal androgen excess may directly hinder folliculogenesis, by an inhibition of aromatase activity in ovarian granulosa cells [7]. Moreover, androgen excess through a feedback mechanism leads to gonadotropin-releasing hormone $(\mathrm{GnRH})$ inhibition, resulting in anovulation or dysovulation [7]. Age at menarche and regularity of the menstrual cycle in women with the classical variant of $\mathrm{CAH}$ depend on the degree of adrenal androgen suppression [27]. Pregnancy rates in women with the classical disease are optimistic for those who try to conceive. However, a large Swedish study of 62 adult women with CAH showed that psychosocial reasons are the most important factors for reduced fertility since less than one-third of patients with null/null mutations were in a heterosexual relationship [15]. On the contrary, patients with SV form of the disease more often opt for pregnancy and successful pregnancy rates have been reported to be higher compared to patients with SW form (92.9 and 88.9\% respectively) [28]. Continued monitoring of hormonal balance and careful readjustment of glucocorticoid doses are necessary to obtain regular ovulatory cycles and optimize fertility [29]. This is not always easy to achieve, especially in noncompliant

Table 2 Follow-up evaluation in adulthood

\begin{tabular}{|c|c|c|}
\hline & Patient 1 & Patient 2 \\
\hline Age at latest evaluation & 35 years & 38 years \\
\hline General appearance in both sisters & \multicolumn{2}{|c|}{$\begin{array}{l}\text { Hirsutism on face with mustache, male distribution of body hair, athletic constitution of body, under- } \\
\text { developed breast }\end{array}$} \\
\hline Current medications in both & \multicolumn{2}{|c|}{ Dexamethasone 0.5 mg/day + hydrocortisone 10 mg/day } \\
\hline Surgical procedures & No surgical procedures & Clitoroplasty and vaginoplasty \\
\hline In vitro fertilization & 2017-ongoing & 2012,2014, 2016-unsuccessfully \\
\hline \multicolumn{3}{|c|}{ Steroid hormone results at latest evaluation-with treatment } \\
\hline 17-OHP (ref. 0.2-2.9 ng/mL) & $29 \mathrm{ng} / \mathrm{mL}$ & $27 \mathrm{ng} / \mathrm{mL}$ \\
\hline Testosterone (ref. $<2.1 \mathrm{nmol} / \mathrm{L}$ ) & $0.087 \mathrm{nmol} / \mathrm{L}$ & $0.93 \mathrm{nmol} / \mathrm{L}$ \\
\hline DHEA-S (ref. 1.65-9.15 $\mu \mathrm{mol} / \mathrm{L})$ & $0.468 \mu \mathrm{mol} / \mathrm{L}$ & $0.494 \mu \mathrm{mol} / \mathrm{L}$ \\
\hline Androstenedione (ref. 3.5 ng/mL) & $1.1 \mathrm{ng} / \mathrm{mL}$ & $2.4 \mathrm{ng} / \mathrm{mL}$ \\
\hline
\end{tabular}


patients. Adequate metabolic control is found in only $30 \%$ of patients with $\mathrm{CAH}$ [30]. Our patients had a long period of poor metabolic control and irregular cycles before getting married and seeking children. Hoepffner et al. [16] reported that adequate combination of mineralocorticoids and glucocorticoids can help sexually active patients with classical CAH to conceive, thus emphasizing the importance of adding mineralocorticoid replacement therapy [16]. Furthermore, ovulation induction and assisted reproductive techniques are now available to women who remain infertile despite effective adrenal androgen suppression [31]. Severe hyperandrogenism, as in our patients, might cause GnRH suppression hindering the ovulation. Elevated progesterone levels can adversely affect the quality of harvested oocytes and implantation which might have been the reason for repeated IVF failure in our patient. Some authors try high doses of corticosteroids to suppress progesterone [28]. If pregnancy is successful, it is usually normal with good fetal outcomes [32].

Fertility in patients with the SV form of CAH depends on the mutation, long-term metabolic control, and successful hormonal management before conception. IVF cannot be successful if the other pre-requisites are not met. Studies involving more females with SV CAH, carrying P30L mutation, are needed to precisely assess its influence upon fertility.

\footnotetext{
Abbreviations

ACTH: adrenocorticotropic hormone; $\mathrm{CAH}$ : congenital adrenal hyperplasia; DHEA-S: dehydroepiandrosterone sulfate; FSH: follicle-stimulating hormone; GnRH: gonadotropin-releasing hormone; 17-OHP: 17-hydroxyprogesterone; IVF: in vitro fertilization; LH: luteinizing hormone; SV: simple virilizing; SW: salt wasting.
}

\section{Acknowledgements}

We thank Dr. Elena Kocova for language editing of this manuscript.

\begin{abstract}
Authors' contributions
MK: diagnosis, treatment and following up of the patients, designing, writing and editing of the manuscript, searching the literature. VA: performing molecular analysis, interpretation of the data, designing, writing and editing the manuscript, searching the literature. IB: treatment and following up of the patients in adulthood. All the authors have accepted responsibility for the entire content of this submitted manuscript. All authors read and approved the final manuscript.
\end{abstract}

\section{Funding}

There was no funding supporting this study.

\section{Availability of data and materials}

The datasets used and/or analyzed during the current study are available from the corresponding author.

\section{Ethics approval and consent to participate}

The study was approved by Human Research Ethics Committees of University Pediatric Clinic, Medical Faculty, Skopje, and the Local Ethics Committee.

\section{Consent for publication}

All of the participants were informed and written consent was obtained when the patients participating in this study.

\section{Competing interests}

The authors declare that they have no competing interests.

\section{Author details \\ ${ }^{1}$ Department of Endocrinology and Genetics, University Clinic of Pedi- atrics, Medical Faculty, Ss. Cyril and Methodius University, Vodnjanska 17, 1000 Skopje, Republic of Macedonia. ${ }^{2}$ University Clinic for Endocrinology, Diabetes and Metabolic Disorders, Medical Faculty, Ss. Cyril and Methodius University, Vodnjanska 17, 1000 Skopje, Republic of Macedonia.}

Received: 24 May 2017 Accepted: 13 June 2019

Published online: 19 June 2019

\section{References}

1. White PC, Speiser PW. Congenital adrenal hyperplasia due to 21-hydroxylase deficiency. Endocrinol Rev. 2000;21:245-91.

2. Miller WL, Morel Y. The molecular genetics of 21-hydroxylase deficiency. Annu Rev Genet. 1989:23:371-93.

3. Speiser PW, Dupont J, Zhu D, Serrat J, Buegeleisen M, Tusie-Luna M-T, Lesser M, New MI, White PC. Disease expression and molecular genotype in congenital adrenal hyperplasia due to 21-hydroxylase deficiency. J Clin Investig. 1992:90:584-95.

4. Dolžan V, Sólyom J, Fekete G, Kovács J, Rakosnikova V, Voltava F, Lebl J, Pribilincova Z, Baumgartner-Parzer SM, Riedl S, Waldhauser F, Frish H, Stopar-Obreza M, Kržišnik C, Battelino T. Mutational spectrum of steroid 21-hydroxylase and the genotype-phenotype association in the Middle European patients with congenital adrenal hyperplasia. Eur J Endocrinol. 2005;153:99-106.

5. Al-Agha A, Ocheltree A, Al-Tamimi M. Association between genotype, clinical presentation and severity of congenital adrenal hyperplasia: a review. Turk J Pediatr. 2012;54:323-32.

6. Piaggio L. Congenital adrenal hyperplasia: review from a surgeon's perspective in the beginning of the twenty-first century. Front Pediatr. 2014;1:1-7.

7. Mnif MF, Kamoun M, Kacem FH, Mnif F, Charfi N, Naceur BB, Rekik N, Abid M. Reproductive outcomes of female patients with congenital adrenal hyperplasia due to 21-hydroxylase deficiency. Indian J Endocr Metab. 2013;17:790-3.

8. Mulaikal RM, Migeon CJ, Rock JA. Fertility rates in female patients with congenital adrenal hyperplasia due to 21-hydroxylase deficiency. N Engl J Med. 1987;316:178-82.

9. Krone N, Riepe FG, Grötzinger J, Partsch CJ, Sippell WG. Functional characterization of two novel point mutations in the CYP21 gene causing simple virilizing forms of congenital adrenal hyperplasia due to 21-hydroxylase deficiency. J Clin Endocrinol Metab. 2005;90:445-54.

10. Menassa R, Tardy V, Despert F, Bouvattier-Morel C, Brossier JP, Cartigny $\mathrm{M}$, Morel Y. p.H62L, a rare mutation of the CYP21 gene identified in two forms of 21-hydroxylase deficiency. J Clin Endocrinol Metab. 2008;93:1901-8.

11. Amor M, Parker KL, Globerman H, New MI, White PC. Mutation in the CYP21B gene (lle-172-Asn) causes steroid 21-hydroxylase deficiency. Proc Natl Acad Sci USA. 1988;85:1600-4.

12. Tusie-Luna MT, Traktman $P$, White PC. Determination of functional effects of mutations in the steroid 21-hydroxylase gene (CYP21) using recombinant vaccinia virus. J Biol Chem. 1990;265:20916-22.

13. Hsu LC, Hsu NC, Guzova JA, Guzov VM, Chang SF, Chang BC. The common I172N mutation causes conformational change of cytochrome P450c21 revealed by systematic mutation, kinetic, and structural studies. J Biol Chem. 1996;271:3306-10.

14. Tusie-Luna MT, Speiser PW, Dumic M, New MI, White PC. A mutation (Pro30 to Leu) in CYP21 represents a potential nonclassic steroid 21-hydroxylase deficiency allele. Mol Endocrinol. 1991:5:685-92.

15. Hagenfeldt K, Janson PO, Holmdahl G, Falhammar H, Filipsson H, Frisén L, Thorén M, Nordenskjöld A. Fertility and pregnancy outcome in women 
with congenital adrenal hyperplasia due to 21-hydroxylase deficiency. Hum Reprod. 2008;23:1607-13.

16. Hoepffner W, Schulze E, Bennek J, Keller E, Willgerodt H. Pregnancies in patients with congenital adrenal hyperplasia with complete or almost complete impairment of 21-hydroxylase activity. Fertil Steril. 2004;81:1314-21.

17. Bose HS, Pescovitz OH, Miller WL. Spontaneous feminization in a $46, X X$ female patient with congenital lipoid adrenal hyperplasia due to a homozygous frameshift mutation in the steroidogenic acute regulatory protein. J Clin Endocrinol Metab. 1997;82:1511-5.

18. Kim CJ. Congenital lipoid adrenal hyperplasia. Ann Pediatr Endocrinol Metab. 2014;19:179-83.

19. Simm PJ, Zacharin MR. Successful pregnancy in a patient with severe 11-betahydroxylase deficiency and novel mutations in CYP11B1 gene. Horm Res. 2007;68:294-7.

20. Levran D, Ben-Shlomo I, Pariente C, Dor J, Mashiach S, Weissman A. Familial partial 17,20-desmolase and 17alpha-hydroxylase deficiency presenting as infertility. J Assist Reprod Genet. 2003;20:21-8.

21. New MI, Lorenzen F, Lerner AJ, Kohn B, Oberfield SE, Pollack MS, Dupont B, Storner E, Levy DJ, Pang S, Levine LS. Genotyping steroid 21-hydroxylase deficiency: hormonal reference data. J Clin Endocrinol Metab. 1983;57:320-6.

22. Lee HH, Chao HT, Ng HT, Choo KB. Direct molecular diagnosis of CYP21 mutations in congenital adrenal hyperplasia. J Med Gen. 1996;33:371-5.

23. New M, Abraham M, Gonzalez B, Dumic M, Razzaghy-Azar M, Chitayat D, Zaidi M, Wilson RC, Yuen T. Genotype-phenotype correlation in 1507 families with congenital adrenal hyperplasia owing to 21-hydroxylase deficiency. Proc Natl Acad Sci USA. 2013;110:2611-6.

24. Anastasovska V, Milenkovic T, Kocova M. Direct molecular diagnosis of CYP21A2 point mutations in Macedonian and Serbian patients with 21-hydroxylase deficiency. J Med Biochem. 2015;34:53-7.
25. Stikkelbroeck NM, Hermus AR, Braat DD, Otten BJ. Fertility in women with congenital adrenal hyperplasia due to 21-hydroxylase deficiency. Obstet Gynecol Surv. 2003;58:275-84.

26. Reisch N, Arlt W, Krone N. Health problems in congenital adrenal hyperplasia due to 21-hydroxylase deficiency. Horm Res Paediatr. 2011;76:73-85.

27. Merke DP. Approach to the adult with congenital adrenal hyperplasia due to 21-hydroxylase deficiency. J Clin Endocrinol Metab. 2008;93:653-60.

28. Casteras A, De Silva P, Rumsby G, Conway GS. Reassessing fecundity in women with classical congenital adrenal hyperplasia (CAH): normal pregnancy rate but reduced fertility rate. Clin Endocrinol. 2009;70:833-7.

29. Grinter HL, Stikkelbroeck NM, Sweep CG, Hermus AR, Otten BJ. Fertility in patients with congenital adrenal hyperplasia. J Pediatr Endocrinol Metab. 2006;19:677-85.

30. Finkielstain GP, Kim MS, Sinaii N, Nishitani M, Van Ryzin C, Hill SC, Reynolds JC, Hanna RM, Merke DP. Clinical characteristics of a cohort of 244 patients with congenital adrenal hyperplasia. J Clin Endocrinol Metab. 2012:97:4429-38

31. Lo JC, Grumbach MM. Pregnancy outcomes in women with congenital virilizing adrenal hyperplasia. Endocrinol Metab Clin N Am. 2001;30:207-29.

32. Krone N, Wachter I, Stefanidou M, Roscher AA, Schwarz HP. Mothers with congenital adrenal hyperplasia and their children: outcome of pregnancy, birth and childhood. Clin Endocrinol. 2001;55:523-9.

\section{Publisher's Note}

Springer Nature remains neutral with regard to jurisdictional claims in published maps and institutional affiliations.
Ready to submit your research? Choose BMC and benefit from:

- fast, convenient online submission

- thorough peer review by experienced researchers in your field

- rapid publication on acceptance

- support for research data, including large and complex data types

- gold Open Access which fosters wider collaboration and increased citations

- maximum visibility for your research: over $100 \mathrm{M}$ website views per year

At $\mathrm{BMC}$, research is always in progress.

Learn more biomedcentral.com/submissions 